\title{
Kenaf Bast Fibers-Part II: Inorganic Nanoparticle Impregnation for Polymer Composites
}

\author{
Jinshu Shi, ${ }^{1}$ Sheldon Q. Shi, ${ }^{1}$ H. Michael Barnes, ${ }^{1}$ Mark F. Horstemeyer, ${ }^{2}$ and Ge Wang ${ }^{3}$ \\ ${ }^{1}$ Forest Products Department (FPD), Mississippi State University (MSU), Box 9820, Starkville, MS 39762-9601, USA \\ ${ }^{2}$ Center for Advanced Vehicular Systems (CAVS), Mississippi State University, Box 5405, Starkville, MS 39762-5405, USA \\ ${ }^{3}$ International Center for Bamboo and Rattan, No. 8 Futong Dongdajie, Wangjing Area, Chaoyang District, Beijing 100102, China
}

Correspondence should be addressed to Sheldon Q. Shi, sshi@cfr.msstate.edu

Received 1 April 2011; Revised 18 June 2011; Accepted 5 July 2011

Academic Editor: Bibin Mathew Cherian

Copyright (c) 2011 Jinshu Shi et al. This is an open access article distributed under the Creative Commons Attribution License, which permits unrestricted use, distribution, and reproduction in any medium, provided the original work is properly cited.

\begin{abstract}
The objective of this study was to investigate an inorganic nanoparticle impregnation (INI) technique to improve the compatibility between kenaf bast fibers and polyolefin matrices. The Scanning Electron Microscopy (SEM) was used to examine the surface morphology of the INI-treated fibers showing that the $\mathrm{CaCO}_{3}$ nanoparticle crystals grew onto the fiber surface. Energy-dispersive X-ray spectroscopy (EDS) was used to verify the $\mathrm{CaCO}_{3}$ nanoparticle deposits on the fiber surface. The tension tests of the individual fiber were conducted, and the results showed that the tensile strength of the fibers increased significantly (more than $20 \%$ ) after the INI treatments. Polymer composites were fabricated using the INI-treated fiber as reinforcement and polypropylene (PP) as the matrix. The results showed that the INI treatments improved the compatibility between kenaf fibers and PP matrix. The tensile modulus and tensile strength of the composites reinforced with INI-treated fibers increased by $25.9 \%$ and $10.4 \%$, respectively, compared to those reinforced with untreated kenaf fibers.
\end{abstract}

\section{Introduction}

Lignocellulosic fiber is a renewable and biodegradable natural polymer which has been used in a variety of applications, such as textile, pulp and paper, and so forth. In recent years, there has been an increasing interest in utilizing natural fibers to replace synthetic glass or carbon fibers to fabricate sheet molding compound (SMC) composites for automobile structural component design. Natural fibers are light weight, economical and environmentally friendly. However, in the processing of lignocellulosic fiber-reinforced polymer composites, the following issues should be addressed. The cell wall structure of natural fibers contains many micropores. If a chemical pulping process is used, additional micropores would be created since some of the lignin and hemicellulose of natural fibers are removed [1]. The presence of these micropores in the cell wall structure could cause manufacturing defects in composites, such as interfacial failure and air pockets. Compatibility between the fiber surface and polymer matrix has been a major issue for lignocellulosic fiber-reinforced polymer composites processing [2-5]. As it was reported in the first paper of this series [6] that the kenaf fibers retted using an alkaline solution by a hermetical process had poor compatibility with the polypropylene (PP) matrix resulting in delaminations of the composites. A common way to improve the compatibility between the cellulosic natural fibers and the polymer matrix is to use coupling agents [7]. However, the organic coupling agents are usually costly and also cause environmental concern. Previous study indicated that the deposited nanoparticles on the fiber surface served as nucleation sites to initiate the crystalline orientation of the molten polymer matrix [8]. Therefore, a proper process to introduce nanoparticles onto the fiber surface serving as attraction force manipulators to polyolefin matrixes has a potential to improve the crystalline formation in the polymer matrix. Since the mechanical behavior of a composite material strongly depends on the adhesion between the reinforced fibers and the matrix, the properties of the composites should be enhanced [9].

Directly impregnating the commercial nanoparticles into the micropore cell wall structure of the cellulosic nature fibers can be difficult and costly. For the inorganic nanoparticle impregnation (INI) process in this study, the primary salt, $\mathrm{Na}_{2} \mathrm{CO}_{3}$, and secondary ionic salt, $\mathrm{CaCl}_{2}$, were impregnated 
into micropores of the fiber cell wall consecutively. The two chemicals react at certain temperature and pressure conditions, and the inorganic nanoparticles of $\mathrm{CaCO}_{3}$ are formed. The chemical reaction is described as follows:

$$
\mathrm{CaCl}_{2} \cdot \mathrm{H}_{2} \mathrm{O}+\mathrm{Na}_{2} \mathrm{CO}_{3} \stackrel{\mathrm{H}_{2} \mathrm{O}}{\longrightarrow} \mathrm{CaCO}_{3}+2 \mathrm{NaCl}+2 \mathrm{H}_{2} \mathrm{O}
$$

The INI technology has been used in pulp, paper, and surface coating industries [10]. The main purpose of INI in pulp and paper was to improve the printability of the papers. The inorganic nanoparticles loaded into cell wall and on the surface may provide strong static electric attractive forces to nonpolar polymer surface [11], and hence the compatibility between the fibers and the polymer matrix may be improved. These nanoparticle-impregnated fibers can be incorporated readily into the existing manufacturing process to make fiber sheets for composite products. The impregnation of the inorganic nanoparticles into the micropore structure of the fiber cell walls can reduce the microvoid volumes in the fiber, as well as reduce air bubble formation during the composite fabrication process. This process is low cost (using inexpensive ionic salts), has little environmental concern (weak chemical solutions are used and can be reused), and simple (the inorganic nanoparticles form directly). The products can be potentially used as vehicle components because of their light-weight, good mechanical properties and environmental friendliness.

In this study, the kenaf bast fibers retted from the hermetical alkaline process were further treated with INI processes. The objectives of this study were to optimize the INI process for the kenaf bast fibers and to evaluate the potentials on the property improvement for the kenaf fiberPP composites.

\section{Materials and Methods}

2.1. Materials. The Kenaf stalks were obtained from MSU North Farm. After the separation of the kenaf core and bast, the bast was cut into $50.8 \mathrm{~mm}$ lengths and dried to a moisture content of $7.4 \%$ at $103^{\circ} \mathrm{C}$. Sodium hydroxide $(\mathrm{NaOH})$ solution $(5 \%, \mathrm{w} / \mathrm{v})$ prepared with $\mathrm{NaOH}$ beads (Lab grade, Thermo Fisher Scientific Inc.) and distilled water was used as digestion agent. Glacial acetic acid (17.4 N, Regent grade, Thermo Fisher Scientific Inc.) was used as a $\mathrm{pH}$ neutralizer. Sodium carbonate $\left(\mathrm{Na}_{2} \mathrm{CO}_{3}\right)$ aqueous solutions $(0.1 \mathrm{~mol} / \mathrm{L})$ and calcium chloride $\left(\mathrm{CaCl}_{2}\right)$ aqueous solutions $(0.1 \mathrm{~mol} / \mathrm{L}$ and $0.2 \mathrm{~mol} / \mathrm{L})$ were prepared, respectively, using distilled water. The sodium carbonate and calcium chloride were supplied by Fisher Scientific Inc. Polypropylene (PP) films (CO-EX Oriented Polypropylene), provided by Plastic Suppliers, Inc. Dallas, Tex, USA, and were used to fabricate kenaf fiber/PP composites.

2.2. INI Treatments. The flowchart on the treatment details is described in Figure $1[5,12,13]$. Kenaf bast was retted with a $5 \% \mathrm{NaOH}$ solution (fiber: $\mathrm{NaOH}$ solution $=1: 30, \mathrm{~g} / \mathrm{mL}$ ) in a hermetical reactor (Parr Instrument Co. $251 \mathrm{M}$ ) at $160^{\circ} \mathrm{C}$. The retting process took one hour and was aided with a mechanical stirring. The autogenous vapor pressure was
$0.60 \mathrm{MPa}$. After the retting process, the $\mathrm{pH}$ of the retting liquid and retted fibers was adjusted to 7.0 using acetic acid. The neutralized fibers were washed with water to remove chemicals from the fibers. These fibers were used as the control fibers. The control fibers and $0.1 \mathrm{~mol} / \mathrm{L} \mathrm{Na}_{2} \mathrm{CO}_{3}$ water solution (fiber: solution $=5: 400, \mathrm{~g} / \mathrm{mL}$ ) were mixed in the hermetic reactor with mechanical stirring at $70^{\circ} \mathrm{C}$ with autogenous vapor pressure of $0.1 \mathrm{MPa}$ for 30 minutes. The excessive primary ionic solution was removed from kenaf fibers by gravity. The secondary ionic solution was used to impregnate the fibers at three different temperatures and autogenous vapor pressures $\left(100^{\circ} \mathrm{C}, 0.15 \mathrm{MPa}\right.$; $130^{\circ} \mathrm{C}, 0.30 \mathrm{MPa}$, and $160^{\circ} \mathrm{C}, 0.70 \mathrm{MPa}$ ) for 15 minutes. The controlled molar ratios of $\mathrm{Na}_{2} \mathrm{CO}_{3}$ to $\mathrm{CaCl}_{2}$ were $1: 1$ and $1: 2$ by the concentration of $\mathrm{CaCl}_{2}$ solution, $0.1 \mathrm{~mol} / \mathrm{L}$ or $0.2 \mathrm{~mol} / \mathrm{L}$. Three temperatures and the corresponding pressures provided a total of six INI treatment conditions. After the impregnation of the two ionic solutions, the primary ionic salt $\left(\mathrm{Na}_{2} \mathrm{CO}_{3}\right)$ reacted with the secondary ionic salt $\left(\mathrm{CaCl}_{2}\right)$ in kenaf bast fibers to generate $\mathrm{CaCO}_{3}$ nanoparticles in the micropore structure of the fiber cell wall, from which the nanoparticle crystals may grow onto the fiber surface. The impregnated fibers were washed to remove excess $\mathrm{CaCO}_{3}$ particles and other ions on fiber surface.

2.3. Determination of $\mathrm{CaCO}_{3}$ Loading. The percentage $\mathrm{CaCO}_{3}$ loading in the fibers was calculated based on the difference in ash contents between the untreated fibers and INI-treated fibers. The ash content was determined by burning the material in a muffle furnace first at $400^{\circ} \mathrm{C}$ for 30 minutes, then at $850^{\circ} \mathrm{C}$ for 45 minutes.

2.4. Characterization of INI-Treated Fibers. Surface morphology, tensile properties of individual fibers, surface hardness, and elastic modulus of the fibers were examined in the same procedures described in the first paper of this series [6]. Elements determination was conducted using a Bruker Quantax 200 X Flash Energy-Dispersive X-ray Spectrometer (EDS) System (LN2-free high speed $30 \mathrm{~mm}^{2}$ SDD Detector).

2.5. Composites Fabrication. The composites were fabricated with a sheet molding compound process. The control fibers and INI-treated kenaf fibers were dispersed in water by vigorous mechanical stirring. The fiber suspension was poured into a $355 \mathrm{~mm} \times 355 \mathrm{~mm}$ deckle box and then passed through a screen (mesh 35 ), on which the fiber sheets were formed as the water flowed down gravitationally. The fiber sheets were dried in an oven set at $80^{\circ} \mathrm{C}$. The fiber sheets and PP films were cut into a dimension of $15.2 \mathrm{~cm} \times$ $15.2 \mathrm{~cm}$ and laminated alternatively. The fiber to PP weight ratio in the composite panel was 50:50. The laminated mats were pressed at $200^{\circ} \mathrm{C}$ and $0.7 \mathrm{MPa}$ for 2.5 minutes. The pressure was not released until the platen was cooled to room temperature. The kenaf fiber/PP panels were removed from the press and stored in a desiccator with the silica gel for two days before preparing the mechanical testing specimens. Three panels were fabricated for each formula. The density of all of the kenaf fiber/PP composites (including the control 


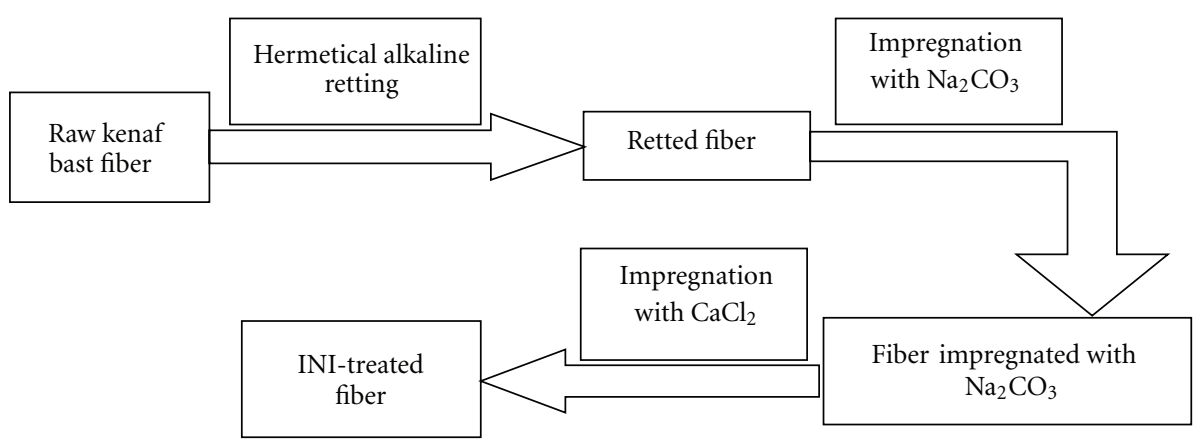

FIGURE 1: Flowchart of INI treatment.

fibers reinforced and INI-treated fibers-reinforced composites) was $0.88 \pm 0.03 \mathrm{~g} / \mathrm{cm}^{3}$.

2.6. Composites Tensile Properties Testing. Tensile properties of the INI-treated fiber/PP composites and control fiber (untreated fiber)/PP composites were tested with Instron 5869 (load cell $50 \mathrm{kN}$ ). The crosshead extensions were used as the specimen deformations. Composites samples were kept in desiccators for one week before tensile testing. The procedures referred to ASTM 1037. The crosshead speed during the tension testing was $2.5 \mathrm{~mm} / \mathrm{min}$. Nine replicates of each composite formulation were tested. Multiple comparison of the results was conducted with Fisher's Least Square method at $\alpha=0.05$ using SAS 9.2 software (SAS Institute Inc. NC, USA). The fracture surfaces of the samples were observed using scanning electron microscopy (SEM, Zeiss Supra TM 40).

\section{Results and Discussion}

3.1. CaCO3 Loading. Table 1 shows the loading percentage of $\mathrm{CaCO}_{3}$ in the fibers. Each specimen was examined twice, and the errors were less than $0.1 \%$. The fibers treated at $130^{\circ} \mathrm{C}$ $\left(\mathrm{Na}_{2} \mathrm{CO}_{3}\right.$ to $\left.\mathrm{CaCl}_{2}=1: 1, \mathrm{~mol}: \mathrm{mol}\right)$ had the highest $\mathrm{CaCO}_{3}$ loading. Although the differences in the loading percentages of $\mathrm{CaCO}_{3}$ among the impregnation variables were no more than $1 \%$, a small increase in $\mathrm{CaCO}_{3}$ nanoparticle loading could result in a significant change in surface characteristics of the fibers since the particles impregnated in were in nano scales and with a high specific surface area. A small amount of $\mathrm{CaCO}_{3}$ nanoparticles may give a large surface area, which may have a significant impact on the interfacial compatibility between the fiber and the polymer matrix.

3.2. Surface Morphology and Element Determination. Figure 2 shows the SEM images of the fiber surfaces treated with INI. As the temperature increased, the inorganic nanoparticle size increased, indicating that temperature played an important role in the formation of $\mathrm{CaCO}_{3}$ crystals. The sizes of the $\mathrm{CaCO}_{3}$ nanoparticles in the fibers treated at $100^{\circ} \mathrm{C}$ and $130^{\circ} \mathrm{C}$ were smaller than $90 \mathrm{~nm}$. However, some $\mathrm{CaCO}_{3}$ particles generated at $160^{\circ} \mathrm{C}\left(\mathrm{Na}_{2} \mathrm{CO}_{3}: \mathrm{CaCl}_{2}=1: 1\right.$, $\mathrm{mol}: \mathrm{mol})$ grew to a diameter over nanoscale.
TABLE 1: $\mathrm{CaCO}_{3}$ loading percentages of the INI-treated fibers.

\begin{tabular}{lcc}
\hline \multicolumn{3}{c}{ INI treatment conditions } \\
Temperature $\left({ }^{\circ} \mathrm{C}\right)$ & $\begin{array}{c}\mathrm{Na}_{2} \mathrm{CO}_{3}: \mathrm{CaCl}_{2} \\
(\mathrm{~mol}: \mathrm{mol})\end{array}$ & $\mathrm{CaCO}_{3}$ loading $(\%)$ \\
\hline 100 & $1: 1$ & 1.91 \\
100 & $1: 2$ & 2.30 \\
130 & $1: 1$ & 2.86 \\
130 & $1: 2$ & 2.57 \\
160 & $1: 1$ & 2.43 \\
160 & $1: 2$ & 2.21 \\
\hline
\end{tabular}

The EDS spectrum and elements maps are shown in Figures 3 and 4 . In the spectrum, calcium (Ca), carbon $(\mathrm{C})$, and oxygen $(\mathrm{O})$ were detected indicating that the $\mathrm{CaCO}_{3}$ nanoparticles exist in the fibers. Calcium may exist as calcium ion $\left(\mathrm{Ca}^{2+}\right)$ with $\mathrm{Cl}^{-}$ion or in $\mathrm{CaCO}_{3}$ molecule. Since, neither sodium $(\mathrm{Na})$ nor chlorine $(\mathrm{Cl})$ was detected from the EDX. Therefore, Calcium can only exist in $\mathrm{CaCO}_{3}$. This evidence testified that the reaction between $\mathrm{Na}_{2} \mathrm{CO}_{3}$ and $\mathrm{CaCl}_{2}$ occurred during the INI process and the $\mathrm{CaCO}_{3}$ was synthesized. The byproduct, $\mathrm{NaCl}$, would have been washed off after the INI treatment. The peaks for gold $(\mathrm{Au})$ and palladium (Pd) came from the specimens coating treatment for the SEM and EDS.

3.3. Surface Hardness and Elastic Modulus. Table 2 shows the surface hardness and elastic modulus of the INI-treated fibers.

The fibers treated at $130^{\circ} \mathrm{C}(0.30 \mathrm{MPa})$ yielded a $52.6-$ $76.9 \%$ increase in modulus and a $47.0-59.1 \%$ increase in hardness. The improvement of the hardness and modulus properties was found for the other INI treated fibers also compared with the untreated fiber. The micropores in the cell wall of the lignocellulosic fibers were filled up by the $\mathrm{CaCO}_{3}$ particles, which enhanced the stress transfer between cellulose fibrils resulting a higher hardness and modulus. A higher variation in the hardness and modulus properties was found in Table 2. This may be because that some indentation tests are on the $\mathrm{CaCO}_{3}$, while others on the fibers. In addition, the component variation at different locations of 


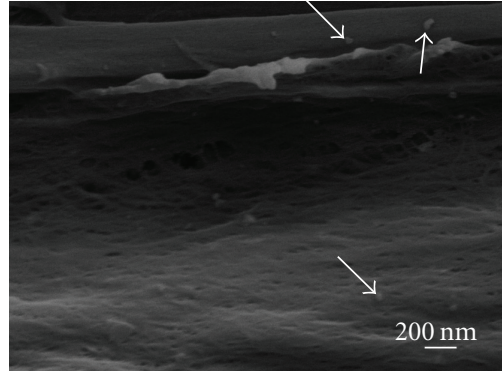

(a)

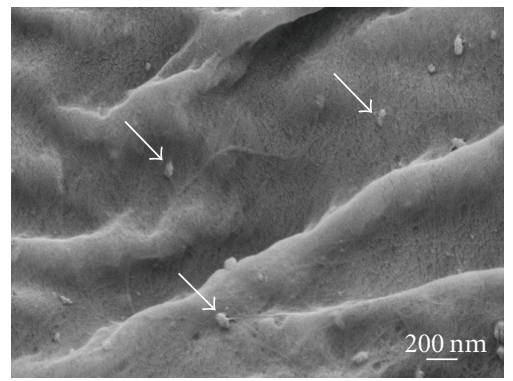

(d)

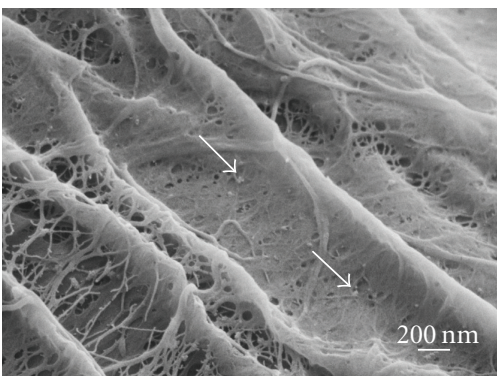

(b)

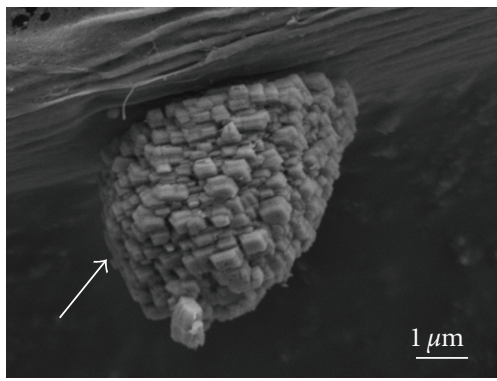

(e)

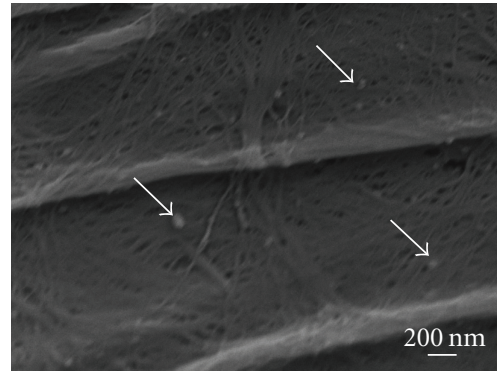

(c)

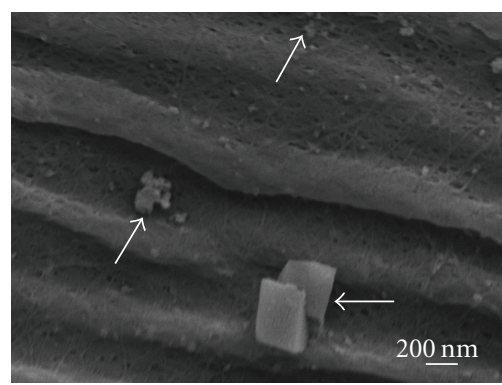

(f)

Figure 2: SEM images of INI-treated fibers. (a) $100^{\circ} \mathrm{C}\left(\mathrm{Na}_{2} \mathrm{CO}_{3}: \mathrm{CaCl}_{2}=1: 1, \mathrm{~mol}: \mathrm{mol}\right)$, (b) $100^{\circ} \mathrm{C}\left(\mathrm{Na}_{2} \mathrm{CO}_{3}: \mathrm{CaCl}=1: 2, \mathrm{~mol}: \mathrm{mol}_{2}\right),(\mathrm{c})$ $130^{\circ} \mathrm{C}\left(\mathrm{Na}_{2} \mathrm{CO}_{3}: \mathrm{CaCl}_{2}=1: 1, \mathrm{~mol}: \mathrm{mol}\right)$, (d) $130^{\circ} \mathrm{C}\left(\mathrm{Na}_{2} \mathrm{CO}_{3}: \mathrm{CaCl}_{2}=1: 2, \mathrm{~mol}: \mathrm{mol}\right)$ at $1: 2$, (e) $160^{\circ} \mathrm{C}\left(\mathrm{Na}_{2} \mathrm{CO}_{3}: \mathrm{CaCl}_{2}=1: 1, \mathrm{~mol}: \mathrm{mol}\right)$, and (f) $160^{\circ} \mathrm{C}\left(\mathrm{Na}_{2} \mathrm{CO}_{3}: \mathrm{CaCl}_{2}=1: 2, \mathrm{~mol}: \mathrm{mol}\right)$. The white arrows designated the $\mathrm{CaCO}_{3}$ particles.

TABLE 2: Surface hardness and elastic modulus of the INI treated fibers.

\begin{tabular}{|c|c|c|c|c|c|c|c|}
\hline \multicolumn{2}{|c|}{ INI treatment conditions } & \multicolumn{3}{|c|}{ Surface hardness (MPa) } & \multicolumn{3}{|c|}{ Elastic modulus (GPa) } \\
\hline Temperature $\left({ }^{\circ} \mathrm{C}\right)$ & $\mathrm{Na}_{2} \mathrm{CO}_{3}: \mathrm{CaCl}_{2}, \mathrm{~mol}: \mathrm{mol}$ & Mean & Stdev. & LSD & Mean & Stdev. & LSD \\
\hline & Untreated fiber & 287.91 & 113.75 & A & 4.64 & 1.73 & A \\
\hline 100 & $1: 1$ & 264.83 & 26.36 & A & 4.88 & 0.43 & A \\
\hline 100 & $1: 2$ & 272.31 & 51.35 & A & 5.40 & 0.68 & A \\
\hline 130 & $1: 1$ & 423.25 & 47.89 & B & 7.08 & 0.78 & $\mathrm{~B}$ \\
\hline 130 & $1: 2$ & 458.19 & 112.81 & B & 8.21 & 1.03 & $\mathrm{~B}$ \\
\hline 160 & $1: 1$ & 213.26 & 87.56 & A & 4.30 & 1.00 & A \\
\hline 160 & $1: 2$ & 295.57 & 42.39 & A & 5.28 & 0.50 & A \\
\hline
\end{tabular}

Stdev.: means standard deviation. Average of four samples. Means with the different letter are significantly different at $\alpha=0.05$.

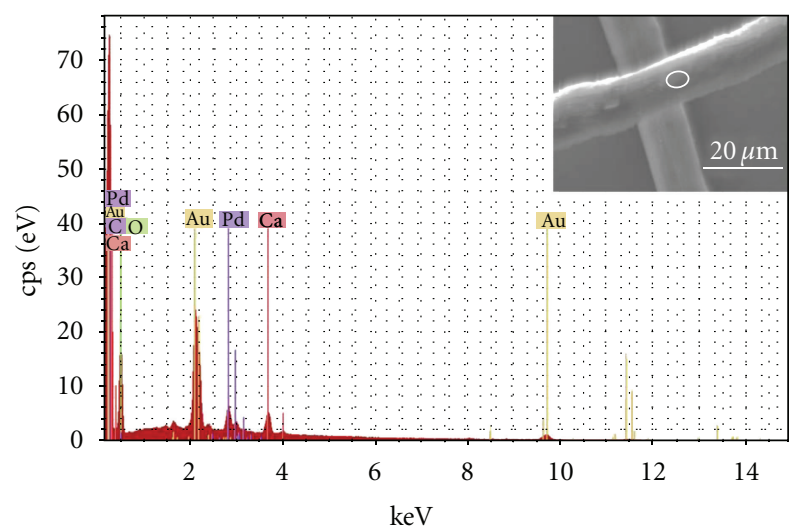

Figure 3: EDS spectrum of kenaf fiber treated with INI process at $100^{\circ} \mathrm{C}, \mathrm{Na}_{2} \mathrm{CO}_{3}: \mathrm{CaCl}_{2}=1: 2, \mathrm{~mol}: \mathrm{mol}$. The white circle designated the point that was analyzed. the fiber itself would also cause the variation in hardness and modulus properties.

3.4. Tensile Properties of Individual Fibers. The tensile properties of the individual fibers are shown in Table 3.

Table 3 shows the tensile property comparison for the INI-treated and -untreated fibers. The results showed that the INI treatments improved the tensile properties. While the improvement in tensile modulus did not show statistically different ( $\alpha=0.05$ ), the tensile strength of the fibers increased significantly after the INI treatments. A $27 \%$ increase in tensile strength (from $810 \mathrm{MPa}$ to $1,032 \mathrm{MPa}$ ) was obtained for the fiber treated at $160^{\circ} \mathrm{C}\left(\mathrm{Na}_{2} \mathrm{CO}_{3}: \mathrm{CaCl}_{2}\right.$ $=1: 2, \mathrm{~mol}: \mathrm{mol})$. The improvement in the tensile strength should be attributed to the impregnation of $\mathrm{CaCO}_{3}$ particles in fiber cell wall, which increases the density of the fibers and 

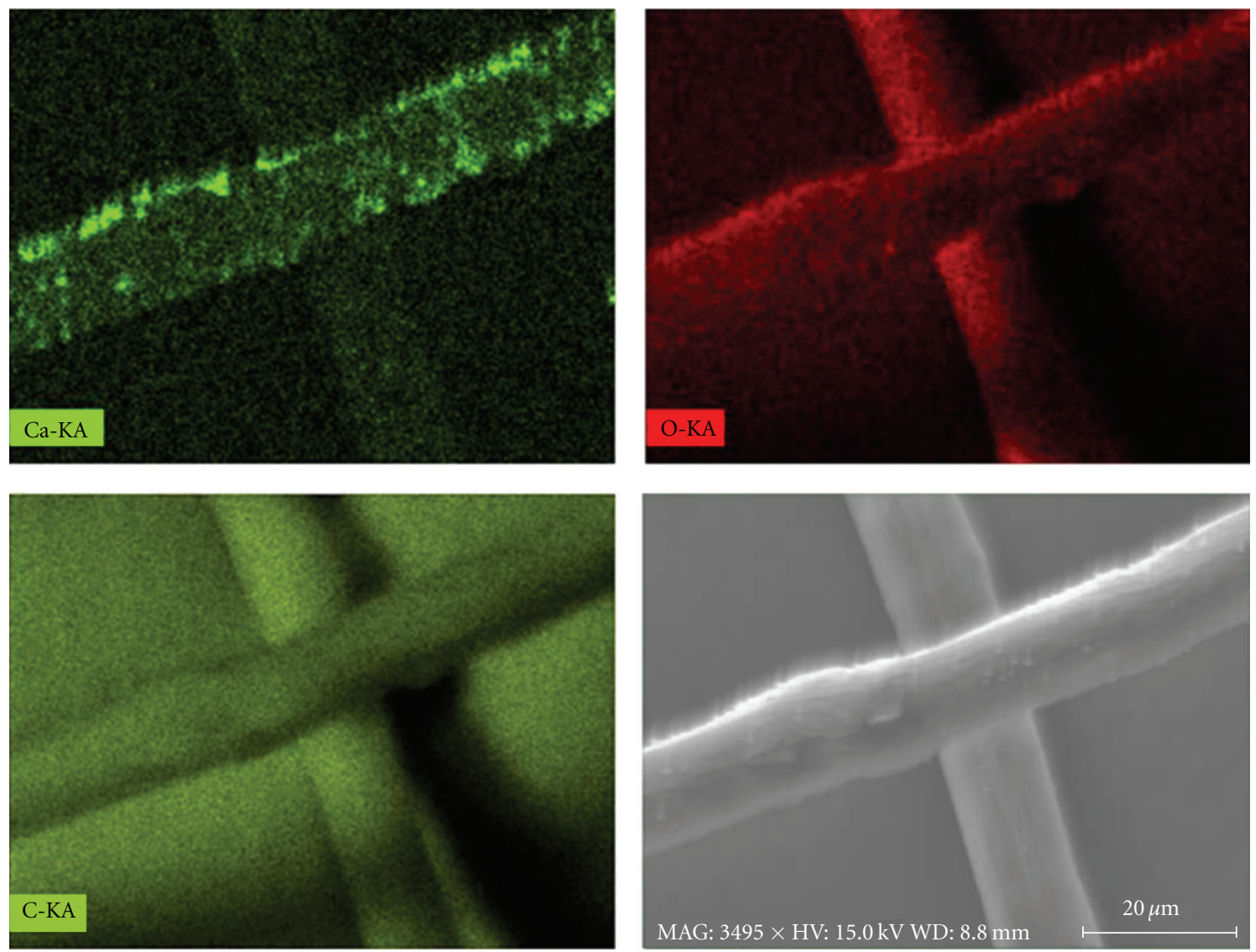

Figure 4: EDS elements mapping of kenaf fiber treated with INI process at $100^{\circ} \mathrm{C}\left(\mathrm{Na}_{2} \mathrm{CO}_{3}: \mathrm{CaCl}_{2}=1: 2, \mathrm{~mol}: \mathrm{mol}\right)$. Left top: calcium (Ca). Right top: oxygen (O). Left bottom: carbon (C). Right bottom: SEM image.

reduces the defect for the fiber by filling up the micropores. The $\mathrm{CaCO}_{3}$ particles in the fiber also helped for the stress transfer between the cellulose fibrils, yielding the overall tensile strength improvement.

\subsection{Tensile Properties of INI Treated Fiber/PP Composites.} The tensile strength and tensile modulus of INI treated fiber/PP composites are shown in Table 4.

For most of the treatment conditions, the PP composites reinforced with the INI-treated fibers showed improvement in both tensile strength and tensile modulus. Except for the fibers treated at $100^{\circ} \mathrm{C}\left(\mathrm{Na}_{2} \mathrm{CO}_{3}: \mathrm{CaCl}_{2}=1: 1, \mathrm{~mol}: \mathrm{mol}\right)$, significant improvement in tensile strength was found for all other combinations. The INI treatment condition at $\left(100^{\circ} \mathrm{C}, \mathrm{Na}_{2} \mathrm{CO}_{3}: \mathrm{CaCl}_{2}=1: 2, \mathrm{~mol}: \mathrm{mol}\right)$ showed the best reinforcing effects compared to other conditions, with about $10.4 \%$ increase in tensile strength. No significant difference in tensile strength was found among the six INI treatment conditions.

The improvement in tensile modulus of the composites does correlate with the INI treatment conditions. INI treatment significantly increased tensile modulus for all combinations. The composites reinforced with the fibers treated at $160^{\circ} \mathrm{C}\left(\mathrm{Na}_{2} \mathrm{CO}_{3}: \mathrm{CaCl}_{2}=1: 1, \mathrm{~mol}: \mathrm{mol}\right)$ gave the
TABLE 3: Tensile properties of individual fibers.

\begin{tabular}{lcccc}
\hline $\begin{array}{l}\text { INI treatment } \\
\text { conditions }\end{array}$ & $\begin{array}{c}\text { Modulus } \\
(\mathrm{GPa})\end{array}$ & LSD Test & $\begin{array}{c}\text { Strength } \\
(\mathrm{MPa})\end{array}$ & LSD test \\
\hline Untreated fiber & 13.5 & $\mathrm{~A}$ & 810 & $\mathrm{~A}$ \\
$100^{\circ} \mathrm{C}, 1: 2$ & 14.7 & $\mathrm{~A}$ & 1001 & $\mathrm{~B}$ \\
$160^{\circ} \mathrm{C}, 1: 2$ & 14.6 & $\mathrm{~A}$ & 1032 & $\mathrm{~B}$ \\
\hline
\end{tabular}

$1: 2$ means the molar ratio of $\mathrm{Na}_{2} \mathrm{CO}_{3}$ to $\mathrm{CaCl}_{2}$. Average of 30 samples. Means with the different letter are significantly different at $\alpha=0.05$.

highest tensile modulus, which was $25.9 \%$ higher than those reinforced with untreated fibers.

The typical stress-strain curves of the INI-treated fiber/PP composites are shown in Figure 5. Since the load taken up by the fibers decreases as the strain increases [14], the tensile behaviors of the composites drive to plastic deformation, and the slopes of the stress-strain curves become smaller as the strain increases. The dislocation of INI-treated kenaf fibers in the composites may occur under a higher load than untreated fibers do because $\mathrm{CaCO}_{3}$ particles modified the compatibility between kenaf fiber and PP matrix. Therefore, the initial slopes of the stress-strain curves are higher for the INI-treated fiber/PP composites than that for the untreated fiber/PP composites, and the elongations of the 


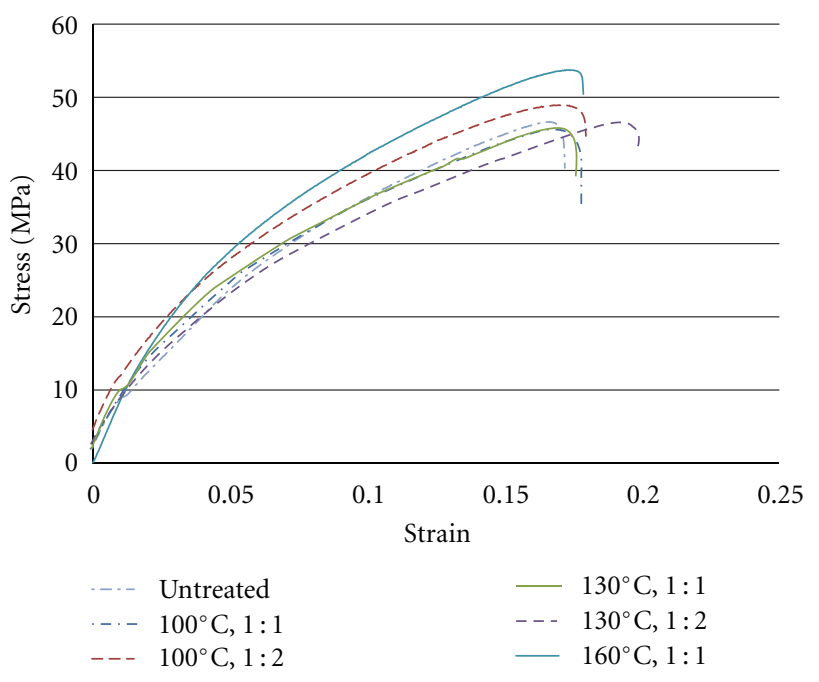

Figure 5: Stress-strain curves of the INI-treated fiber/PP composites. The labels mean the INI treatments conditions for the kenaf fibers. Untreated fiber is the control fiber that has been retted at $160^{\circ} \mathrm{C}$ but not treated with INI processes.

TABLE 4: Tensile strength and tensile modulus of INI treated fiber/PP composites.

\begin{tabular}{lcccccc}
\hline & \multicolumn{3}{c}{ Tensile Strength (MPa) } & \multicolumn{3}{c}{ Tensile Modulus (GPa) } \\
INI treatments & Mean & Stdev. & $\begin{array}{c}\text { LSD } \\
\text { Test }\end{array}$ & Mean & Stdev. & $\begin{array}{c}\text { LSD } \\
\text { Test }\end{array}$ \\
\hline Untreated & 46.77 & 3.43 & $\mathrm{~A}$ & 1.70 & 0.20 & $\mathrm{~A}$ \\
$100^{\circ} \mathrm{C}, 1: 1$ & 49.23 & 3.77 & $\mathrm{AB}$ & 1.88 & 0.11 & $\mathrm{~B}$ \\
$100^{\circ} \mathrm{C}, 1: 2$ & 51.65 & 2.57 & $\mathrm{~B}$ & 1.96 & 0.15 & $\mathrm{BC}$ \\
$130^{\circ} \mathrm{C}, 1: 1$ & 50.20 & 3.30 & $\mathrm{~B}$ & 1.93 & 0.22 & $\mathrm{BCD}$ \\
$130^{\circ} \mathrm{C}, 1: 2$ & 51.61 & 2.51 & $\mathrm{~B}$ & 2.05 & 0.11 & $\mathrm{DE}$ \\
$160^{\circ} \mathrm{C}, 1: 1$ & 51.41 & 4.33 & $\mathrm{~B}$ & 2.14 & 0.22 & $\mathrm{E}$ \\
$160^{\circ} \mathrm{C}, 1: 2$ & 50.94 & 4.31 & $\mathrm{~B}$ & 1.99 & 0.16 & $\mathrm{BE}$ \\
\hline $1: 1 \mathrm{na}$ & & & & & &
\end{tabular}

$1: 1$ and $1: 2$ means the molar ratio of $\mathrm{Na}_{2} \mathrm{CO}_{3}$ to $\mathrm{CaCl}_{2}$. Average of 27 samples. Means with the same letter are not significantly different at $\alpha=$ 0.05. Stdev: standard deviation of the mean.

INI-treated fiber/PP composites were higher than that of the untreated fiber/PP composites.

The mechanical property improvement for the kenaf fiber/PP composites should be attributed to the improvement in interfacial bonding between the fiber and PP matrix. Figure 6 shows the SEM images for the fracture surfaces of fiber/PP composites with both the INI-treated fibers (two treatment conditions) and -untreated fibers. Fiber pullout is clearly shown at the fracture surface for the composites with untreated fibers (Figure 6(a)) indicating poor interfacial compatibility between untreated fibers and PP. However, for the composites with INI-treated fibers, more simultaneous failure was observed. The interfacial compatibility between the INI-treated fiber and PP matrix was much improved compared to the control samples, indicating stronger adhesion between the fiber and the PP matrix. It may be reasoned that the inorganic nanoparticles deposited on the fiber surface served as the nucleation sites to initiate the crystalline

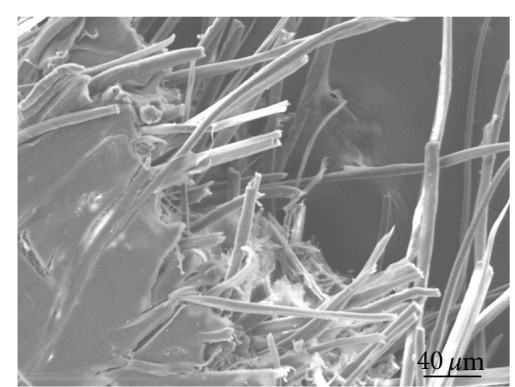

(a)

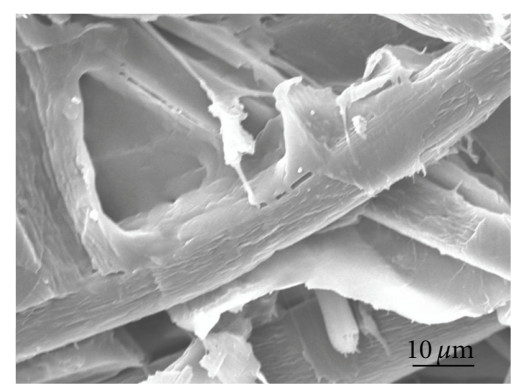

(b)

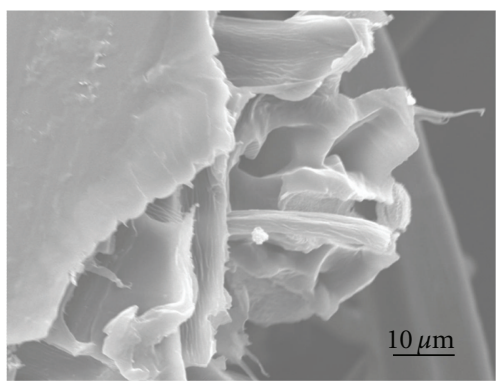

(c)

FIGURE 6: SEM images of the fracture surfaces of kenaf fiber/PP composites. (a) PP composites reinforced with untreated fibers; (b) $\mathrm{PP}$ composites reinforced with INI-treated fibers (INI treatment conditions were $100^{\circ} \mathrm{C}, \mathrm{Na}_{2} \mathrm{CO}_{3}: \mathrm{CaCl}_{2}=1: 2, \mathrm{~mol}: \mathrm{mol}$ ), and (c) $\mathrm{PP}$ composites reinforced with INI-treated fibers (INI treatment conditions were $160^{\circ} \mathrm{C}, \mathrm{Na}_{2} \mathrm{CO}_{3}: \mathrm{CaCl}_{2}=1: 1, \mathrm{~mol}: \mathrm{mol}$ ).

formation of the semicrystalline polymer matrix around the fibers.

\section{Conclusions}

Inorganic nanoparticles $\left(\mathrm{CaCO}_{3}\right)$ were successfully impregnated into kenaf bast fibers. From the SEM images, the nanoparticle deposition is clearly observed on the fiber surfaces. INI treatment $\left(\right.$ at $130^{\circ} \mathrm{C}$ ) increased the surface hardness of the fiber by $52.6-76.9 \%$ and the elastic modulus by $47.0-59.1 \%$. The fibers treated at $160^{\circ} \mathrm{C}$ with INI processes yielded a $27 \%$ improvement in tensile strength. The impregnated inorganic nanoparticles improved the compatibility between the fibers and the PP matrix, resulting in an increase in tensile modulus and tensile strength of the kenaf fiber/PP composites. Based on the current lab condition, the INI treatment conditions including 
(1) $130^{\circ} \mathrm{C}, 1: 1 \quad\left(\mathrm{Na}_{2} \mathrm{CO}_{3}: \mathrm{CaCl}_{2}, \mathrm{~mol}: \mathrm{mol}\right),(2) 160^{\circ} \mathrm{C}$, $1: 1 \quad\left(\mathrm{Na}_{2} \mathrm{CO}_{3}: \mathrm{CaCl}_{2}, \mathrm{~mol}: \mathrm{mol}\right)$, and (3) $160^{\circ} \mathrm{C}, 1: 2$ $\left(\mathrm{Na}_{2} \mathrm{CO}_{3}: \mathrm{CaCl}_{2}, \mathrm{~mol}: \mathrm{mol}\right)$ produced the optimal kenaf fibers that had the best reinforcement effects for PP. The $\mathrm{PP}$ composites reinforced with the INI-treated $\left(160^{\circ} \mathrm{C}, 1: 1\right)$ fibers showed a $10.4 \%$ improvement in tensile strength and $25.9 \%$ in tensile modulus compared to those reinforced with untreated fibers.

\section{Acknowledgments}

The research work was supported by Department of Energy (DOE), funding no. 362000-060803 through Center for Advanced Vehicular System (CAVs) at Mississippi State University and National Science Foundation (NSF), fund no. CMMI0928641 09080796. Acknowledgments are given to Dr. Jinwu Wang for the help with the data analysis, Dr. Sangyeob Lee for the involvement of the project when he worked as a post-doc at Mississippi State University, and USDA-Forest Service Southern Research Station, Pineville, La, USA and the International Center for Bamboo and Rattan, Beijing, China for the instrumental support. The manuscript is approved for publication by Forest and Wildlife Research Center (FWRC), Mississippi State University. The FWRC Publication No. FP609.

\section{References}

[1] G. G. Allan, J. P. Carroll, A. R. Negri, M. Raghuraman, P. Ritzenthaler, and A. Yahiaoui, "The microporosity of pulp: the precipitation of inorganic fillers within the micropores of the cell wall," TAPPI Journal, vol. 75, no. 1, pp. 175-178, 1992.

[2] S. Q. Shi, D. J. Gardner, and J. Z. Wang, "Surface properties of polymer automobile fluff particles characterized by inverse gas chromatography and contact angle analysis," in Proceedings of the 4th International Conference on Wood Fiber-Plastics Composites, pp. 245-256, Forest Products Society, Madison, Wis, USA, May 1997.

[3] S. Y. Lee, Transcrystallization behavior and interfacial strength of a semicrystalline polymer combined with thermomechanical pulp (TMP) fiber, M.S. thesis, Moscow, Idaho, USA, University of Idaho, 2002.

[4] C. G. Ma, M. Z. Rong, M. Q. Zhang, and K. Friedrich, "Irradiation-induced surface graft polymerization onto calcium carbonate nanoparticles and its toughening effects on polypropylene composites," Polymer Engineering and Science, vol. 45, no. 4, pp. 529-538, 2005.

[5] S. Lee, S. Q. Shi, and M. H. Barnes, "Multifunctional nanoparticles at the hydrophilic and hydrophobic interface," in Proceedings of the Advanced Biomass Science and Technology for Bio-Based Products, pp. 173-181, Chinese Academy of Forestry, Beijing, China, May 2007.

[6] J. Shi, S. Q. Shi, H. M. Barnes, M. Horstemeyer, J. Wang, and E. B .M. Hassan, "Kenaf bast fibers_-part I: hermetical alkali digestion," International Journal of Polymer Science, vol. 2011, Article ID 212047, 8 pages, 2011.

[7] C. Clemons and A. R. Sanadi, "Instrumented impact testing of kenaf fiber reinforced polypropylene composites: effects of temperature and composition," Journal of Reinforced Plastics and Composites, vol. 26, no. 15, pp. 1587-1602, 2007.
[8] S. Y. Lee, T. F. Shupe, L. H. Groom, and C. Y. Hse, "Heterogeneous nucleation of a semicrystalline polymer on fiber surfaces," in Recent Developments in the Particleboard, Fiberboard, and Molded Wood Products Industry, T. E. Shupe, Ed., pp. 99-105, Forest Products Society, 2006.

[9] J. M. Park, T. Q. Son, J. G. Jung, and B. S. Hwang, "Interfacial evaluation of single Ramie and Kenaf fiber/epoxy resin composites using micromechanical test and nondestructive acoustic emission," Composite Interfaces, vol. 13, no. 2-3, pp. 105-129, 2006.

[10] J. Kuusipalo, M. Kaunisto, A. Laine, and M. Kellomäki, "Chitosan as a coating additive in paper and paperboard," Tappi Journal, vol. 4, no. 8, pp. 17-21, 2005.

[11] S. Y. Lee, Some factors affecting the interfacial interaction at thermomechanical fiber and polypropylene interphase, Ph.D. Dissertation, Louisiana State University, Baton Rouge, La, USA, 2006.

[12] S. Q. Shi, S. Lee, and J. Shi, "Lamination process for chemical retted kenaf fiber/thermoplastic polymer composites," in Proceedings of the 23rd Annual American Society for Composites Technical Conference, Memphis. Tenn, USA, September 2008.

[13] S. Q. Shi, S. Lee, and M. Horstemeyer, "Natural fiber retting and inorganic nanoparticle impregnation treatment for natural fiber/polymer composites," in Proceedings of the American Society for Composites, University of Washington, Seattle, Wash, USA, September 2007.

[14] R. M. Rowell, R. Jacobson, and D. Caulfield, "Properties of kenaf/polypropylene composites," in Kenaf Properties, Processing and Products, chapter 32, pp. 381-392, Mississippi State University, Ag \& Bio Engineering, Starkville, Miss, USA, 1999. 

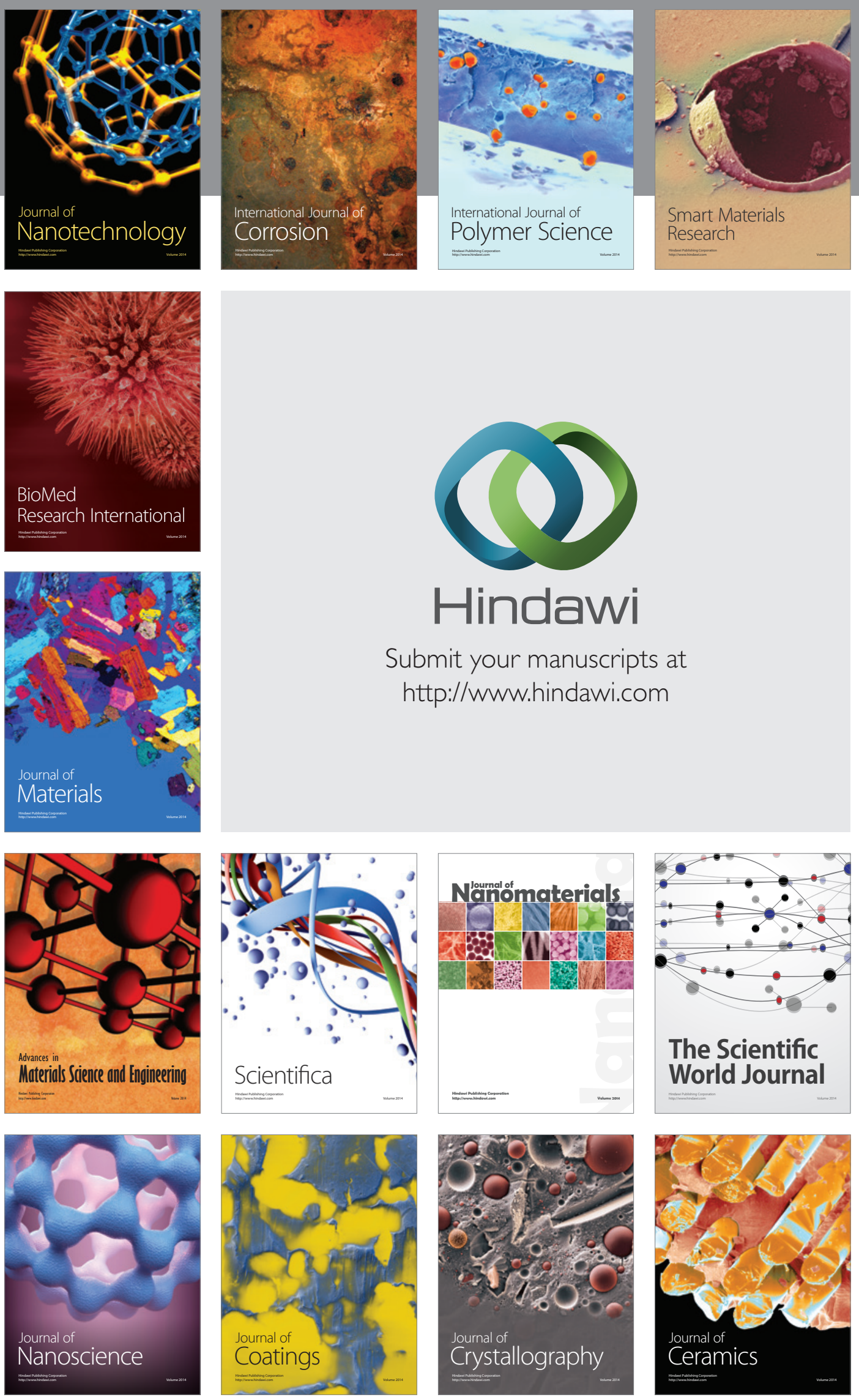

The Scientific World Journal

Submit your manuscripts at

http://www.hindawi.com

\section{World Journal}

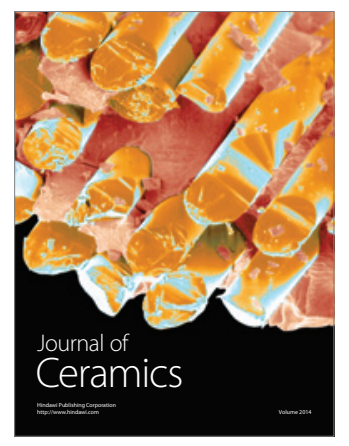

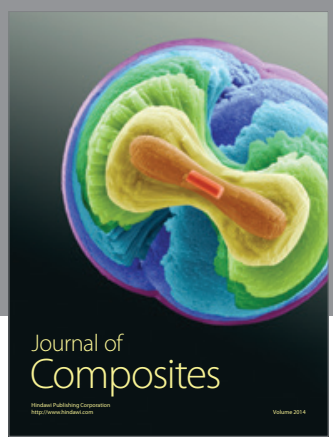
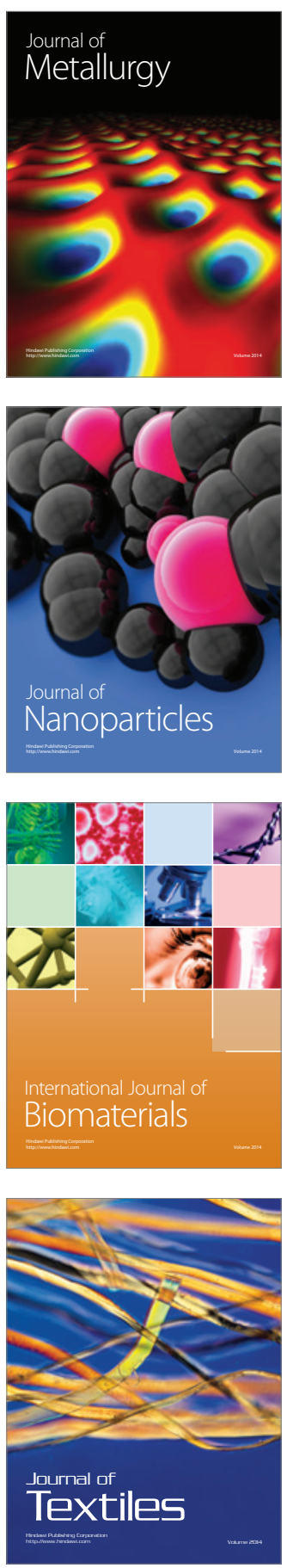